Communication

\title{
The Bovine Antimicrobial Peptide Lactoferricin Interacts with Polysialic Acid without Loss of Its Antimicrobial Activity against Escherichia coli
}

\author{
Andrea Kühnle ${ }^{1,2}$, Christina E. Galuska ${ }^{1,2}$, Kristina Zlatina ${ }^{1}$ (D) and Sebastian P. Galuska ${ }^{1,2, *}$ \\ 1 Institute of Reproductive Biology, Leibniz Institute for Farm Animal Biology (FBN), Wilhelm-Stahl-Allee 2, \\ 18196 Dummerstorf, Germany; kuehnle@fbn-dummerstorf.de (A.K.); \\ Galuska.christina@fbn-dummerstorf.de (C.E.G.); Zlatina@fbn-dummerstorf.de (K.Z.) \\ 2 Institute of Biochemistry, Faculty of Medicine, Justus-Liebig-University, Friedrichstr. 24, \\ 35392 Giessen, Germany \\ * Correspondence: galuska.sebastian@fbn-dummerstorf.de; Tel.: +49-38208-68-769
}

Received: 6 November 2019; Accepted: 15 December 2019; Published: 18 December 2019

check for updates

Simple Summary: Bovine milk contains a high concentration of the protein lactoferrin. It is an important antimicrobial biomolecule, which is also present in other bodily fluids like blood and semen. However, not only the intact protein but also its cleavage products have antimicrobial activity. Perhaps, the best-known cleavage product of lactoferrin is the peptide lactoferricin that has significant antimicrobial capacity against a broad range of pathogens such as enterohemorrhagic Escherichia coli (EHEC). Interestingly, lactoferricin can interact with the sugar polymer polysialic acid, which is also present in milk, blood, and semen. In the present study, we tested if the binding to polysialic acid influences the biological activity of bovine lactoferricin. Remarkably, neither different amounts of polysialic acid nor different chain lengths of this sugar polymer influenced the antimicrobial activity of lactoferricin. The ability of polysialic acid to bind and not inactivate lactoferricin may allow the development of novel endogenous and biodegradable polysialylated surfaces and/or hydrogels, which can be loaded with the antimicrobial peptide lactoferricin for biomedical applications in veterinary and human medicine.

Abstract: The lactoferrin-derived peptide lactoferricin (LFcin) belongs to the family of antimicrobial peptides, and its bovine form has already been successfully applied to counteract enterohemorrhagic Escherichia coli (EHEC) infection. Recently, it was described that LFcin interacts with the sugar polymer polysialic acid (polySia) and that the binding of lactoferrin to polySia is mediated by LFcin, included in the N-terminal domain of lactoferrin. For this reason, the impact of polySia on the antimicrobial activity of bovine LFcin was investigated. Initially, the interaction of LFcin was characterized in more detail by native agarose gel electrophoresis, demonstrating that a chain length of 10 sialic acid residues was necessary to bind LFcin, whereas approximately twice-as-long chains were needed to detect binding of lactoferrin. Remarkably, the binding of polySia showed, independently of the chain length, no impact on the antimicrobial effects of LFcin. Thus, LFcin binds polySia without loss of its protective activity as an antimicrobial peptide.

Keywords: lactoferrin; lactoferricin; polysialic acid; sialic acids; antimicrobial peptides; innate immune system

\section{Introduction}

Lactoferrin is a multifunctional iron-binding glycoprotein with strong ability to modulate and support the immune system [1-7]. Interestingly, lactoferrin can be found in nearly all bodily fluids. 
Lactoferrin can be excreted by epithelial cells, and the highest amounts have been determined in breast milk [8,9]. Besides epithelial cells, neutrophil granulocytes belong to the major producer of lactoferrin and, thus, high concentrations of lactoferrin can be found at inflammatory hotspots $[7,8,10]$.

Recently, the linear carbohydrate polysialic acid (polySia) has been identified as a probable binding partner for lactoferrin [11,12]. The building units of this polysaccharide are sialic acids, a group of $\alpha$-keto acids with a nine-carbon backbone [13]. The sialic acid residues are mainly attached to each other via $\alpha 2,9$ and/or $\alpha 2,8$ linkages [14]. In mammals, however, only $\alpha 2,8$-linked polymers, consisting of $\mathrm{N}$-acetylneuraminic acid (Neu5Ac) residues, seem to be generated, modulating numerous physiological processes, such as the development of the brain and other organs, in addition to immunological mechanisms [13,15-22]. Interestingly, polySia and lactoferrin can be detected in the same bodily fluids, such as ejaculates, blood, and milk, suggesting that polySia influences the functional properties of lactoferrin [1,12,23-25]. Indeed, polySia has been shown to support the activity of lactoferrin in inhibiting the release of neutrophil extracellular traps (NET) [3,12]. NET is a pathogen-catching meshwork of decondensed DNA and antimicrobial molecules that can be formed by neutrophil granulocytes during inflammation [26], and polySia is only one example of several carbohydrate-based mechanisms that influence the formation and functionality of NET [27]. Besides the interplay with lactoferrin during NET formation, polySia seems to modulate the binding of lactoferrin to DNA of already-released NET filaments [11]. This might be possible, since both DNA and polySia molecules mainly interact with the N-terminal domain of lactoferrin [11,28]. This domain is one of the main structural differences between lactoferrin and its iron-transporting family member, transferrin. Interestingly, this cationic domain can be released under acidic conditions or by proteolytic cleavage with pepsin. The resulting peptide is called lactoferricin (LFcin), and besides mammalian proteases, bacterial enzymes are also able to initiate the release of LFcin. The formation of LFcin and other antimicrobial degradation products of lactoferrin was observed in the stomach and other areas during inflammation [6,29-31]. The proteolytic release might be an advantage due to the commonly stronger antimicrobial activity of LFcin compared to lactoferrin [5,6,29,32-34]. These antibacterial effects, in addition to the observation that bacteria show increasing resistance against antibiotics, make LFcin an interesting alternative or additional therapeutic agent in veterinary and human medicine [34].

It has already been shown that polySia interacts with the LFcin-containing domain in lactoferrin, as well as with the released antimicrobial peptide LFcin [11,12]. Remarkably, polySia also interacts with histones [35,36], which are, like LFcin, denoted as antimicrobial peptides [37-39]. Besides the best known function of histones in the packaging of DNA, extracellular histones and their fragments are part of the innate immune system [40], and their antimicrobial capacities have been described in many animal classes, such as insects, fish, amphibians, birds, and mammals [41-45]. In the case of histones, it is known that polySia influences their interactions and/or activity in a chain-length-dependent manner [46-48]. However, this interaction does not necessarily have an effect on the functionality of the interaction partners. For instance, the antimicrobial activity of histone $\mathrm{H} 3$ is inhibited by polySia, whereas those of the lysine-rich histone $\mathrm{H} 1$ is not affected in the presence of polySia [49]. For this reason, we wanted to investigate if polySia has an impact on the antimicrobial capacity of LFcin. To this end, we first characterized the interaction of LFcin and polySia in more detail by using native gel electrophoresis and ELISA with defined chain lengths of polySia. Furthermore, the impact of LFcin on bacterial growth was investigated in the presence of polySia.

\section{Materials and Methods}

\subsection{Materials}

The reagents used for all the following experiments were of analytical grade. The Escherichia coli strain BL21 (DE3) was kindly provided by the lab of Joachim Weitzel. In the experiments, lactoferrin from bovine milk (Sigma-Aldrich, Steinheim, Germany), bovine LFcin (B25; Bachem, Bubendorf, Switzerland), Neu5Ac (MonoSia; Carbosynth, Compton, UK), and colominic acid (polySia) (Gerbu, 
Heidelberg, Germany) were used. Lipopolysaccharides (LPS) were removed from polySia with C18 cartridges (ThermoFisher Scientific, Dreieich, Germany), as described in the manufacturer's manual.

\subsection{Fractionation and Analysis of Neu5Ac Polymers}

In order to obtain polySia fractions with defined degrees of polymerization (DP), commercially available polySia (a heterogeneous mixture of different chain lengths) was separated by anion-exchange chromatography $[46,47]$. To receive greater amounts of shorter polySia chain lengths (for native agarose gel electrophoresis and competitive ELISA), polySia was previously partially hydrolyzed. Therefore, polySia was incubated in a reaction buffer $(9 \mathrm{mM}$ sodium hydrosulfite, $0.5 \mathrm{M} \beta$-mercaptoethanol, $20 \mathrm{mM}$ trifluoroacetic acid [TFA]) for $45 \mathrm{~min}$ at $55^{\circ} \mathrm{C}$. To stop the hydrolysis, $20 \% 1 \mathrm{M} \mathrm{NaOH}(v / v)$ was added. PolySia separation took place with MilliQ water (E1) and $2 \mathrm{M}$ ammonium acetate buffer (E2) on a DNAPac ${ }^{\mathrm{TM}}$ PA100 column ( $22 \mathrm{~mm} \times 250 \mathrm{~mm}, 13 \mu \mathrm{m}$; ThermoFisher Scientific) at a flow rate of $2.5 \mathrm{~mL} / \mathrm{min}$. The gradient was the following: $0 \mathrm{~min}=0 \%(v / v) \mathrm{E} 2,5 \mathrm{~min}=0 \%(v / v) \mathrm{E} 2,20 \mathrm{~min}=26 \%$ $(v / v) \mathrm{E} 2,30 \mathrm{~min}=34 \%(v / v) \mathrm{E} 2,45 \mathrm{~min}=38 \%(v / v) \mathrm{E} 2,85 \mathrm{~min}=44 \%(v / v) \mathrm{E} 2,110 \mathrm{~min}=100 \%(v / v) \mathrm{E} 2$, $140 \mathrm{~min}=100 \%(v / v) \mathrm{E} 2,141 \mathrm{~min}=0 \%(v / v)$ E2. To remove ammonium acetate, the samples were dried by lyophilization and evaporation.

Then, $0.01 \%$ of the gained fractions were quantified with the eluents methanol/acetonitrile/water/ trifluoroacetic acid (TFA) (4:4:92:0.1; E3) and methanol/acetonitrile/water/TFA (45:45:10:0.1; E4) on a Superspher $100 \mathrm{C}-18$ column $(250 \mathrm{~mm} \times 40 \mathrm{~mm}$; Merck-Hitachi, Darmstadt, Germany). After hydrolysis in $0.2 \mathrm{M}$ TFA for $4 \mathrm{~h}$ at $80^{\circ} \mathrm{C}$, the samples were dried, and Neu5Ac residues were labeled with 4,5-methylene dioxybenzene (DMB) in $80 \mu \mathrm{L} \mathrm{DMB}$ reaction buffer $(9 \mathrm{mM}$ sodium hydrosulfite, $0.5 \mathrm{M}$ $\beta$-mercaptoethanol, $20 \mathrm{mM}$ TFA) for $2 \mathrm{~h}$ at $55^{\circ} \mathrm{C}$; the reaction was stopped with $20 \mu \mathrm{L} 0.2 \mathrm{M} \mathrm{NaOH}$ $(v / v)[50,51]$. The used gradient was the following: $0 \mathrm{~min}=0 \%(v / v) \mathrm{E} 4,2 \mathrm{~min}=0 \%(v / v) \mathrm{E} 4,25 \mathrm{~min}=$ $5 \%(v / v) \mathrm{E} 4,31 \mathrm{~min}=100 \%(v / v) \mathrm{E} 4,40 \mathrm{~min}=100 \%(v / v) \mathrm{E} 4,41 \mathrm{~min}=0 \%(v / v) \mathrm{E} 4,55 \mathrm{~min}=100 \%(v / v)$ E4. The flow rate was $0.25 \mathrm{~mL} / \mathrm{min}$.

To control the separated chain lengths, $100 \mathrm{ng}$ of each fraction was mildly labeled with DMB in $80 \mu \mathrm{L} \mathrm{DMB}$ reaction buffer (overnight at $11^{\circ} \mathrm{C}$ ), and $20 \mathrm{ng}$ were analyzed with a DNAPac ${ }^{\mathrm{TM}}$ PA100 column ( $4 \mathrm{~mm} \times 250 \mathrm{~mm}, 13 \mu \mathrm{m}$; ThermoFisher Scientific) [52]. The used gradient was the following: $0 \mathrm{~min}=0 \%(v / v) \mathrm{E} 2,5 \mathrm{~min}=0 \%(v / v) \mathrm{E} 2,15 \mathrm{~min}=5 \%(v / v) \mathrm{E} 2,30 \mathrm{~min}=21 \%(v / v) \mathrm{E} 2,55 \mathrm{~min}=33 \%$ $(v / v) \mathrm{E} 2,100 \mathrm{~min}=43 \%(v / v) \mathrm{E} 2,101 \mathrm{~min}=100 \%(v / v) \mathrm{E} 2,110 \mathrm{~min}=100 \%(v / v) \mathrm{E} 2,111 \mathrm{~min}=100 \%(v / v)$ E2. The flow rate was $1 \mathrm{~mL} / \mathrm{min}$. PolySia digested with active endoneuraminidase (EndoN, $0.1 \mu \mathrm{g}$ ) was analyzed under the same conditions.

\subsection{Electrophorese on Native Agarose Gel}

For the interaction analysis, lactoferrin and LFcin were separated by native gel electrophoresis in the absence and presence of Neu5Ac and different chain length of polySia, as previously described in detail $[12,53]$. To this end, the samples were loaded on an agarose gel $(2 \%, w / v)$ (lactoferrin and LFcin, $10 \mu \mathrm{g} / \mathrm{lane}$; Neu5Ac and sialic acid polymers, $5 \mu \mathrm{g} / \mathrm{lane}$ ) and separated for $5 \mathrm{~h}$ at $80 \mathrm{~V}$ (running buffer: $25 \mathrm{mM}$ Tris/ $\mathrm{HCl}, 19.2 \mathrm{mM}$ glycine, $\mathrm{pH}$ 8.5). Afterwards, the proteins were fixed in $45 \%$ methanol/7.5\% acetic acid $(v / v)$ overnight and colored with Coomassie blue (Roti-Blue, Carl-Roth), and the gel was de-stained with $25 \%$ methanol.

\subsection{ELISA}

ELISA plates were coated with $20 \mu \mathrm{g} / \mathrm{mL}$ of lactoferrin (coating buffer, $15 \mathrm{mM} \mathrm{Na}_{2} \mathrm{CO}_{3}, 35 \mathrm{mM}$ $\mathrm{NaHCO}_{3}, \mathrm{pH}$ 9.6) for $2 \mathrm{~h}$, followed by two washing steps. Afterwards, Neu5Ac and polySia fractions $(160 \mu \mathrm{g} / \mathrm{mL}$ in PBS) were added, and incubation was carried out for $2 \mathrm{~h}$. In a further step, murine anti-LFcin antibody $(0.5 \mu \mathrm{g} / \mathrm{mL})$ was applied to bind unoccupied LFcin binding sides. For a detailed description, please see [12]. 


\subsection{Bacterial Growth Assay}

Bacterial growth was analyzed with the Bacteria Counting Colorimetric Assay Kit (BioVision, Milpitas, CA, USA), which was also used to characterize the impact of histones on E. coli [49]. During all the following steps, E. coli was cultured at $37^{\circ} \mathrm{C}$ under shaking. To generate a preculture, LB medium $(1 \% \mathrm{NaCl}[w / v], 1 \%$ peptone $[w / v], 0.5 \%$ yeast extract $[w / v])$ was inoculated with a frozen $E$. coli stock and incubated overnight. With this preculture, a main culture was inoculated and grown until an OD $(600 \mathrm{~nm})$ of $0.29-0.32$ was reached. For the bacterial growth experiments, $50 \mu \mathrm{L}$ of LB medium was added to a 96-well plate. In addition, LB medium containing LFcin $(200 \mu \mathrm{g} / \mathrm{mL})$ and/or polySia (400, 200 , or $100 \mu \mathrm{g} / \mathrm{mL})$, Neu5Ac $(400 \mu \mathrm{g} / \mathrm{mL})$, fractionated polySia $(400 \mu \mathrm{g} / \mathrm{mL})$, or enzymatically cleaved polySia $(400 \mu \mathrm{g} / \mathrm{mL})$ was applied. For the enzymatic digestion of the polymers, polySia $(6 \mathrm{mg} / \mathrm{mL})$ was treated with endo $\mathrm{N}\left(6.7 \mu \mathrm{g} / \mathrm{mL}, 3 \mathrm{~h}, 37^{\circ} \mathrm{C}\right)$. To the $50 \mu \mathrm{L}$ of differently modified LB media, $40 \mu \mathrm{L}$ of bacteria solution $\left(\sim 2.4 \times 10^{8}\right.$ bacteria/mL) and $10 \mu \mathrm{L}$ of WST/ECS solution (reagents of the Bacteria Counting Colorimetric Assay Kit) were added. Thus, the final concentration of LFcin is $100 \mu \mathrm{g} / \mathrm{mL}$. The bacterial growth was measured for $150 \mathrm{~min}$ in 30 min intervals, at a wavelength of $450 \mathrm{~nm}$.

\subsection{Statistical Analysis}

The calculated values were analyzed with Graph Pad Prism 8.2.1 software using ANOVA and a multiple-comparison Turkey test. Differences were considered statistically significant at $p<0.05$. Statistically significant differences are indicated: ns, not significant; ${ }^{*} p<0.05 ;{ }^{* *} p<0.01$; ${ }^{* * *} p<0.001$; $* * * * p<0.0001$.

\section{Results and Discussion}

\subsection{A Lower DP of PolySia Is Sufficient to Mediate the Binding to LFcin in Comparison to Lactoferrin}

Antimicrobial peptides act together as a functional complex to attack the bacterial membrane [54]. If a switch of several LFcin molecules from one polySia chain to the bacterial membrane is possible, it is conceivable that such an accumulation of several LFcin molecules on a polySia chain supports the cooperation of the peptides in the formation of damaging complexes. The LFcin peptides would be directly located in a functional neighborhood.

To calculate the loading capacity of a polySia chain, it is important to determine the precise number of linked sialic acid residues which are needed to initiate the interaction. In polySia, the degree of polymerization necessary for the interaction with human lactoferrin or bovine LFcin was previously narrowed down to fractions consisting of polymers with a DP between 15 and 24 sialic acid residues [11,12]. Fractions with shorter chains, consisting of 2 up to 14 linked Neu5Ac residues, showed no reliable interaction with lactoferrin and LFcin in these studies. For the present experiments, groups containing only two main chain lengths (DP 2-3, 4-5, 6-7, 8-9, 10-11, 12-13, 14-15, $16-17,18-19$, and 20-21) were collected. In the collected fractions, the chain lengths were tested by anion-exchange chromatography after fluorescent labeling with DMB (Figure 1a). It was not necessary to collect monoSia, since Neu5Ac is commercially available.

To analyze the ability of polySia to interact with lactoferrin, native agarose gels were loaded with LFcin and/or sialic acid chains of different lengths. In addition, lactoferrin was applied by using an identical experimental setup. Thereby, an interaction could be visualized by a migration shift of the peptide/protein to the positive pole. This migration shift might be caused by the polyanionic charge of polySia during the attachment to its binding partners. In the case of lactoferrin, a first weak interaction may start with a DP of 18-19 (Figure 1b). The fraction DP 20-21 significantly influences the migration of lactoferrin. In contrast, already shorter chains influence the migration of LFcin. Here, a detectable interaction started with DP 10-11 (Figure 1c).

Since lactoferrin is much bulkier than LFcin, it is likely that an interaction with short polySia chains may only slightly influence the migration in the gel. Thus, an interaction with short chains might be overlooked. In order to confirm the obtained results, lactoferrin was coated on ELISA plates. 
Thereafter, polySia fractions according to their DP were added. Subsequently, an antibody against the LFcin-containing domain of lactoferrin was added. The antibody could easily bind the unoccupied $\mathrm{N}$-terminal domain, whereas polySia inhibited the binding [12]. In line with the results from the native agarose gel, polySia with DP 20-21 and unfractionated polySia were able to inhibit the antibody binding (Figure 1d). Thus, in comparison with LFcin, twice-as-long polymers were needed to mediate an interaction.

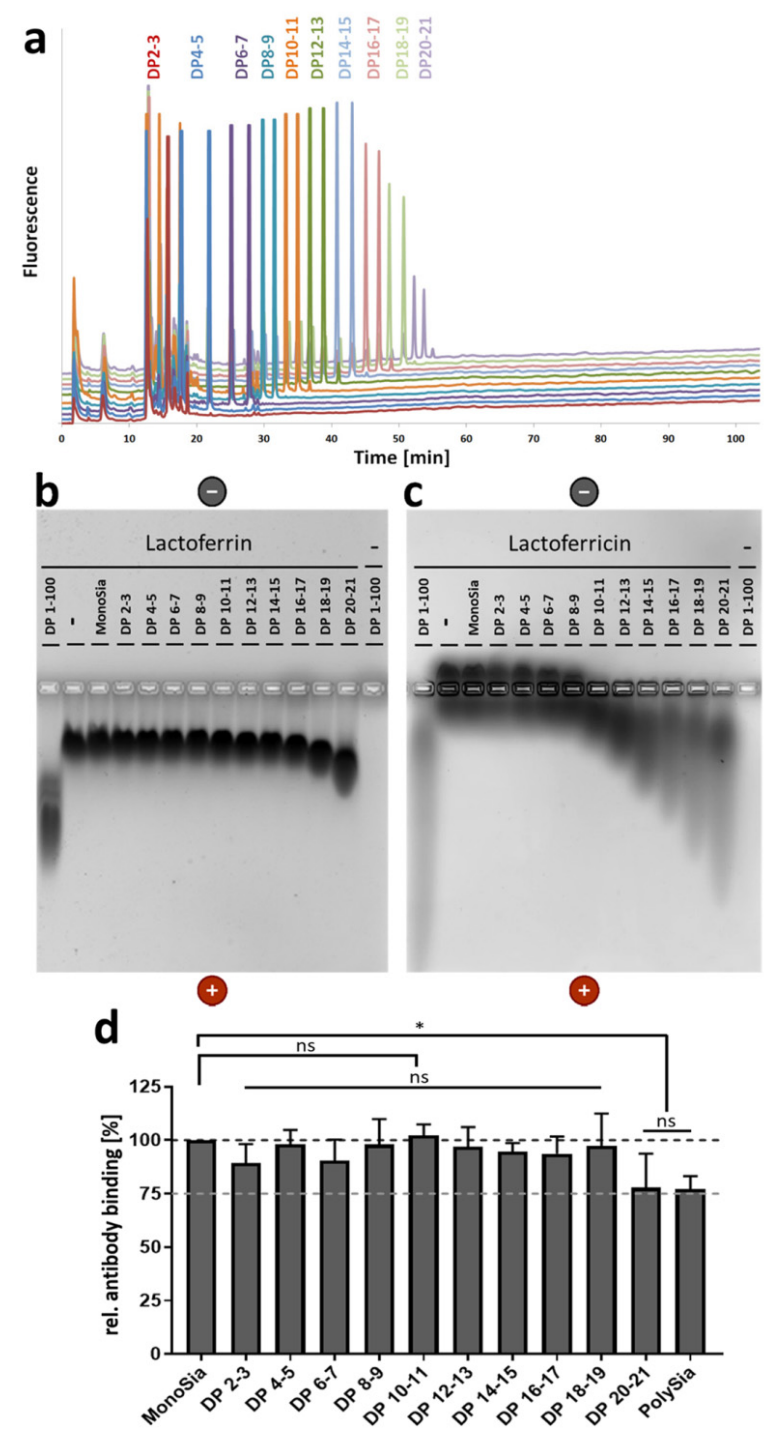

Figure 1. In comparison to lactoferricin (LFcin), higher degrees of polymerization (DPs) are needed for the interaction with lactoferrin. (a) The chain lengths of fractionated polysialic acid (polySia) were analyzed using "mild" dioxybenzene (DMB) labeling and anion-exchange chromatography. (b) Lactoferrin and (c) LFcin were incubated with polySia with chains of defined lengths, and the different samples were analyzed by native gel electrophoresis. In addition, unfractionated polySia ( DP 1-100) was used. Proteins were visualized by staining with Coomassie Blue. To exclude staining of polySia by Coomassie Blue, unfractionated polySia was separated without lactoferrin and LFcin. The gel was loaded with $10 \mu \mathrm{g} / \mathrm{lane}$ of lactoferrin or LFcin and/or $5 \mu \mathrm{g} / \mathrm{mL}$ of carbohydrate. (d) A competitive ELISA with an anti-LFcin antibody was performed by using sialic acid with chains of different lengths. Neu5Ac was used as a negative control and set to $100 \%$. Mean values $(n=3)$ and standard deviations are displayed in the diagram. Statistically significant differences are indicated: nonsignificant (ns) and * $p<0.05$. 
The differences between LFcin and lactoferrin regarding the required chain length for polySia binding might be the results of conformational changes of LFcin after proteolytic release. It is known that bovine LFcin can change its conformation from an $\alpha$-helical structure to a twisted $\beta$-sheet. This transformation might be also the reason for a better binding of LFcin to bacterial membranes and the stronger antibacterial effect of LFcin in comparison to lactoferrin [5,6,55]. In addition, in lactoferrin, large molecular surface areas of LFcin are hidden by other domains of the protein. Furthermore, it needs to be mentioned that molecular dynamic simulation suggested a second binding domain in lactoferrin for the terminal end of a polySia chain [11]. The interaction with two different protein domains is probably needed to stabilize the interaction in the case of lactoferrin.

\subsection{PolySia Has No Impact on the Antimicrobial Activity of LFcin}

To prove the ability of polySia to influence the antibacterial properties of LFcin, both molecules were tested for their ability to inhibit the growth of bacteria. In bacterial growth assays, LFcin and polySia were separately tested, in addition to a combination of LFcin and different concentrations of polySia. As expected, bacterial growth was inhibited by LFcin (Figure 2a,b). In contrast, polySia had no statistically significant impact on bacterial growth (Figure 2b). Surprisingly, when LFcin was applied together with polySia, its antimicrobial activity was not influenced by polySia. The growth curves in the presence or absence of polySia were very similar, and no statistical differences were observed after $150 \mathrm{~min}$.
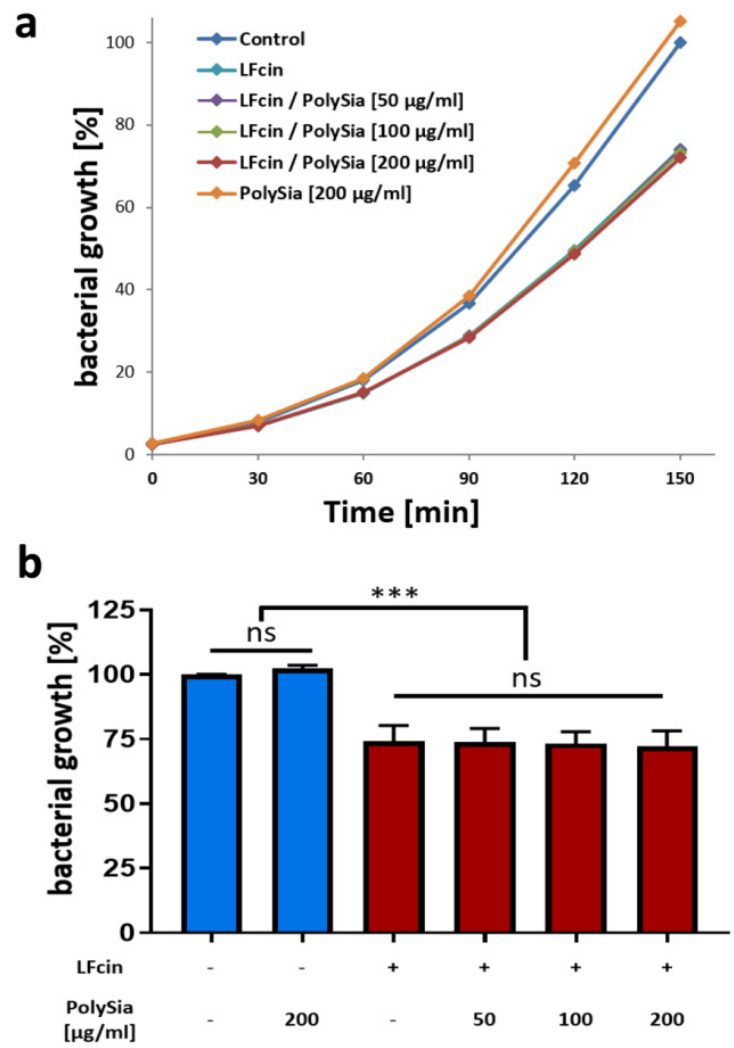

Figure 2. PolySia has no capability to inhibit bacterial growth or the antimicrobial activity of LFcin. (a) Bacteria growth curves were obtained in the absence and presence of LFcin $(100 \mu \mathrm{g} / \mathrm{mL})$ and different amounts of polySia, as indicated in the diagram. In (a), growth curves of an exemplary experiment are depicted. Values at $150 \mathrm{~min}$ are displayed separately in (b). The values for untreated bacteria were set to $100 \%$. Mean values $(n=3)$ and standard deviations are displayed in the diagram. Statistically significant differences are indicated: nonsignificant (ns) and ${ }^{* * *} p<0.001$. 
In order to test weather short or long chains of polySia may have an impact on LFcin's antimicrobial effect, endoN was used to cut the polySia mixture [56]. EndoN works very well because it degrades polySia to mainly short oligomers with a DP $<8$ [57]. The digestion was controlled by anion-exchange chromatography after DMB labeling. The obtained chromatograms demonstrated that the degradation was sufficient (Figure 3a). However, also the resulting fragments of polySia exhibited no ability to influence the effects of LFcin (Figure 3b). As described above, a DP higher than 9 was needed to visualize an impact on the migration of LFcin (Figure 1c). Thus, the obtained degradation products $(\mathrm{DP}<8)$ might be too short.

a

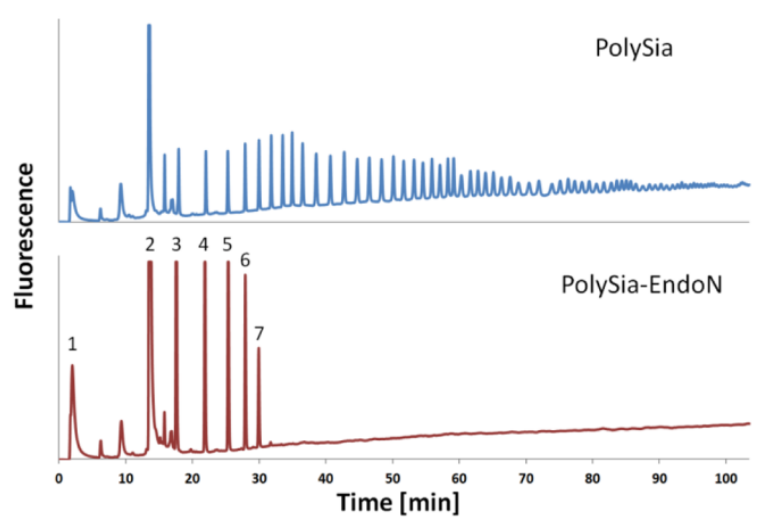

b

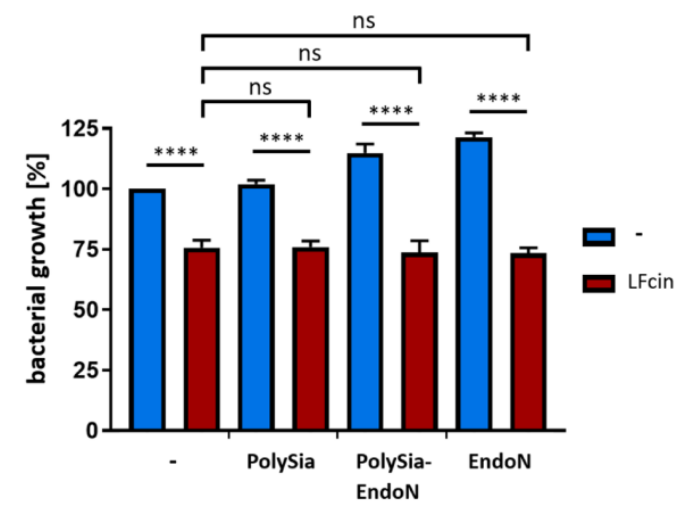

Figure 3. Bacterial growth inhibition by LFcin is not influenced by short sialic acid oligomers. (a) PolySia and polySia degraded by endoN were analyzed by anion-exchange chromatography after "mild" DMB labeling. (b) Bacterial growth values at $150 \mathrm{~min}$ are displayed using polySia $(200 \mu \mathrm{g} / \mathrm{mL})$ or enzymatically degraded polySia $(200 \mu \mathrm{g} / \mathrm{mL})$ in the presence or absence of LFcin $(100 \mu \mathrm{g} / \mathrm{mL})$. Untreated cells were set to $100 \%$. Red bars show LFcin-treated samples, whereas blue bars represent data without LFcin treatment. Mean values $(n=3)$ and standard deviations are displayed in the diagram. Statistically significant differences are indicated: nonsignificant (ns) and ${ }^{* * *} p<0.0001$.

For this reason, five groups of polySia with chain lengths between 8 and 48 were collected, and the DP was analyzed by HPLC (Figure 4a). On the basis of the results of native gel electrophoresis, the chains have the theoretical capacity to bind one to four LFcin molecules. These fractions were used in combination with LFcin for the bacterial growth assays. The results in Figure 4 b clearly depict the capacity of LFcin to inhibit bacterial growth despite the presence of polySia fractions of rising DPs. Thus, polySia can bind LFcin, but it has no impact on its antimicrobial activity. Comparable results were also obtained for histones $\mathrm{H} 1$ and $\mathrm{H} 2 \mathrm{~A}$, as previously described [49]. 

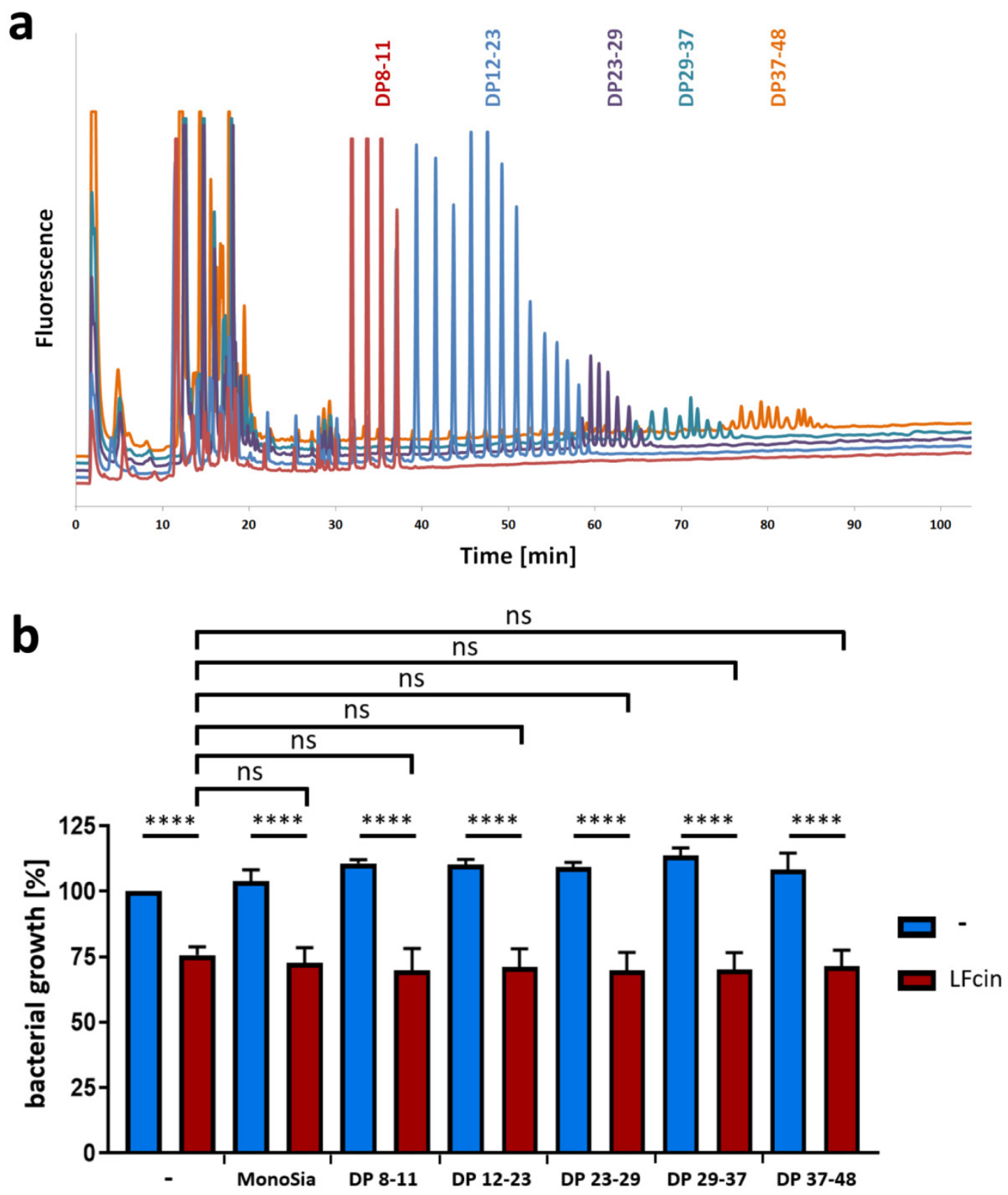

Figure 4. Bacterial growth inhibition by LFcin is not influenced by different chain lengths of polySia. (a) Fractionated polySia samples with different degrees of polymerization (DP 8-48) were analyzed by using "mild" DMB labeling and anion-exchange chromatography. (b) Bacterial growth values after $150 \mathrm{~min}$ are displayed after treatment with LFcin $(100 \mu \mathrm{g} / \mathrm{mL})$ and defined polySia fractions $(200 \mu \mathrm{g} / \mathrm{mL})$. Control (without treatment) was set to $100 \%$. Red bars show LFcin-treated sample datasets, and blue bars show sample datasets without LFcin treatment. Mean values $(n=3)$ and standard deviations are displayed in the diagram. Statistically significant differences are indicated: nonsignificant (ns) and **** $p<0.0001$.

\section{Conclusions}

Interestingly, it was shown that polySia and lactoferrin can interact in several bodily fluids, that polySia supports lactoferrin to inhibit the release of NET, and that polySia influences the binding of lactoferrin to already exposed NET fibers. Since polySia also interacts with the lactoferrin-derived peptide LFcin, an effect of polySia on the biological function of the antimicrobial peptide was also conceivable. Since the binding of lactoferrin is initiated by its LFcin-containing domain, a modulation of LFcin binding to NET or to polysialylated immune cells, such as dendritic cells, is likely [58]. 
Recently, a therapeutic effect of bovine LFcin after oral intake was reported for the prevention of enterohemorrhagic E. coli (EHEC) infection in a mouse model [59], demonstrating, like numerous other studies, the potential of this antimicrobial peptide in veterinary and human medicine (reviewed in [34]). However, neither different amounts of polySia nor different polySia DPs can influence this ability of LFcin. Particularly, the ability to bind and not inactivate LFcin might be a big advantage, if polysialylated surfaces can be loaded with LFcin. One additional point to note is that lactoferrin, LFcin, and polySia are endogenous biomolecules and biodegradable. For this reason, polySia and LFcin might be a powerful combination to develop novel therapeutic strategies, such as polysialylated surfaces and/or hydrogels which can be equipped with the detachable antimicrobial peptide LFcin.

Author Contributions: All authors conceived and designed the experiments. A.K., K.Z., and C.E.G., and S.P.G. performed the experiments and/or analysis. A.K. and S.P.G. wrote the paper. All authors have read and agreed to the published version of the manuscript.

Funding: This work was supported by a grant from the Deutsche Forschungsgemeinschaft (GA 1755/1-2).

Acknowledgments: We are sincerely thankful for their patience and assistance to Gesine Krüger, Torsten Viergutz, and Ursula Antkewitz. We thank Martina Mühlenhoff for generously providing the enzyme EndoN. We thank Joachim Weitzel for the very kind offer of the E. coli strain.

Conflicts of Interest: The authors declare no conflicts of interest. The funders had no role in the design of the study; the collection, analyses, and interpretation of the data; the writing of the manuscript; or in the decision to publish the results.

\section{References}

1. Wang, B.; Timilsena, Y.P.; Blanch, E.; Adhikari, B. Lactoferrin: Structure, function, denaturation and digestion. Crit. Rev. Food Sci. Nutr. 2017, 59, 1-17. [CrossRef] [PubMed]

2. Kruzel, M.L.; Zimecki, M.; Actor, J.K. Lactoferrin in a context of inflammation-induced pathology. Front. Immunol. 2017, 8, 1438. [CrossRef] [PubMed]

3. Okubo, K.; Kamiya, M.; Urano, Y.; Nishi, H.; Herter, J.M.; Mayadas, T.; Hirohama, D.; Suzuki, K.; Kawakami, H.; Tanaka, M.; et al. Lactoferrin suppresses neutrophil extracellular traps release in inflammation. EBioMedicine 2016, 10, 204-215. [CrossRef]

4. Ammons, M.C.; Copie, V. Mini-review: Lactoferrin: A bioinspired, anti-biofilm therapeutic. Biofouling 2013, 29, 443-455. [CrossRef]

5. Vogel, H.J. Lactoferrin, a bird's eye view. Biochem. Cell Biol. 2012, 90, 233-244. [CrossRef]

6. Gifford, J.L.; Hunter, H.N.; Vogel, H.J. Lactoferricin: A lactoferrin-derived peptide with antimicrobial, antiviral, antitumor and immunological properties. Cell. Mol. Life Sci. 2005, 62, 2588-2598. [CrossRef]

7. Legrand, D. Overview of lactoferrin as a natural immune modulator. J. Pediatr-Us 2016, 173, S10-S15. [CrossRef]

8. Levay, P.F.; Viljoen, M. Lactoferrin-A general-review. Haematologica 1995, 80, 252-267.

9. Inoue, M.; Yamada, J.; Kitamura, N.; Shimazaki, K.; Andren, A.; Yamashita, T. Immunohistochemical localization of lactoferrin in bovine exocrine glands. Tissue Cell 1993, 25, 791-797. [CrossRef]

10. Britigan, B.E.; Serody, J.S.; Cohen, M.S. The role of lactoferrin as an anti-inflammatory molecule. In Lactoferrin: Structure and Function; Hutchens, T.W., Rumball, S.V., Lönnerdal, B., Eds.; Springer: Boston, MA, USA, 1994; pp. 143-156.

11. Kuhnle, A.; Lutteke, T.; Bornhofft, K.F.; Galuska, S.P. Polysialic acid modulates the binding of external lactoferrin in neutrophil extracellular traps. Biology 2019, 8, 20. [CrossRef]

12. Kuhnle, A.; Veelken, R.; Galuska, C.E.; Saftenberger, M.; Verleih, M.; Schuppe, H.C.; Rudloff, S.; Kunz, C.; Galuska, S.P. Polysialic acid interacts with lactoferrin and supports its activity to inhibit the release of neutrophil extracellular traps. Carbohydr. Polym. 2019, 208, 32-41. [CrossRef] [PubMed]

13. Schnaar, R.L.; Gerardy-Schahn, R.; Hildebrandt, H. Sialic acids in the brain: Gangliosides and polysialic acid in nervous system development, stability, disease, and regeneration. Physiol. Rev. 2014, 94, 461-518. [CrossRef] [PubMed]

14. Sato, C. Chain length diversity of sialic acids and its biological significance. TIGG 2004, 16, 331-344. [CrossRef] 
15. Colley, K.J.; Kitajima, K.; Sato, C. Polysialic acid: Biosynthesis, novel functions and applications. Crit. Rev. Biochem. Mol. Biol. 2014, 49, 498-532. [CrossRef]

16. Sato, C.; Kitajima, K. Disialic, oligosialic and polysialic acids: Distribution, functions and related disease. J. Biochem. 2013, 154, 115-136. [CrossRef]

17. Galuska, C.E.; Lütteke, T.; Galuska, S.P. Is polysialylated ncam not only a regulator during brain development but also during the formation of other organs? Biology 2017, 6, 27. [CrossRef]

18. Werneburg, S.; Buettner, F.F.; Erben, L.; Mathews, M.; Neumann, H.; Muhlenhoff, M.; Hildebrandt, H. Polysialylation and lipopolysaccharide-induced shedding of e-selectin ligand-1 and neuropilin-2 by microglia and thp-1 macrophages. Glia 2016, 64, 1314-1330. [CrossRef]

19. Kiermaier, E.; Moussion, C.; Veldkamp, C.T.; Gerardy-Schahn, R.; de Vries, I.; Williams, L.G.; Chaffee, G.R.; Phillips, A.J.; Freiberger, F.; Imre, R.; et al. Polysialylation controls dendritic cell trafficking by regulating chemokine recognition. Science 2016, 351, 186-190. [CrossRef]

20. Abe, C.; Yi, Y.; Hane, M.; Kitajima, K.; Sato, C. Acute stress-induced change in polysialic acid levels mediated by sialidase in mouse brain. Sci. Rep. 2019, 9, 9950. [CrossRef]

21. Ulm, C.; Saffarzadeh, M.; Mahavadi, P.; Müller, S.; Prem, G.; Saboor, F.; Simon, P.; Middendorff, R.; Geyer, H.; Henneke, I.; et al. Soluble polysialylated ncam: A novel player of the innate immune system in the lung. Cell. Mol. Life Sci. 2013, 70, 3695-3708. [CrossRef]

22. Zlatina, K.; Saftenberger, M.; Kuhnle, A.; Galuska, C.E.; Gartner, U.; Rebl, A.; Oster, M.; Vernunft, A.; Galuska, S.P. Polysialic acid in human plasma can compensate the cytotoxicity of histones. Int. J. Mol. Sci. 2018, 19, 1679. [CrossRef] [PubMed]

23. Yabe, U.; Sato, C.; Matsuda, T.; Kitajima, K. Polysialic acid in human milk. Cd36 is a new member of mammalian polysialic acid-containing glycoprotein. J. Biol. Chem. 2003, 278, 13875-13880. [CrossRef] [PubMed]

24. Gluer, S.; Wunder, M.A.; Schelp, C.; Radtke, E.; Gerardy-Schahn, R. Polysialylated neural cell adhesion molecule serum levels in normal children. Pediatr. Res. 1998, 44, 915-919. [CrossRef] [PubMed]

25. Simon, P.; Bäumner, S.; Busch, O.; Röhrich, R.; Kaese, M.; Richterich, P.; Wehrend, A.; Müller, K.; Gerardy-Schahn, R.; Mühlenhoff, M.; et al. Polysialic acid is present in mammalian semen as a post-translational modification of the neural cell adhesion molecule ncam and the polysialyltransferase st8siaii. J. Biol. Chem. 2013, 288, 18825-18833. [CrossRef]

26. Brinkmann, V.; Reichard, U.; Goosmann, C.; Fauler, B.; Uhlemann, Y.; Weiss, D.S.; Weinrauch, Y.; Zychlinsky, A. Neutrophil extracellular traps kill bacteria. Science 2004, 303, 1532-1535. [CrossRef]

27. Bornhofft, K.F.; Galuska, S.P. Glycans as modulators for the formation and functional properties of neutrophil extracellular traps: Used by the forces of good and evil. Front. Immunol. 2019, 10, 959. [CrossRef]

28. van Berkel, P.H.; Geerts, M.E.; van Veen, H.A.; Mericskay, M.; de Boer, H.A.; Nuijens, J.H. N-terminal stretch $\arg 2$, arg3, arg4 and arg 5 of human lactoferrin is essential for binding to heparin, bacterial lipopolysaccharide, human lysozyme and DNA. Biochem. J. 1997, 328, 145-151. [CrossRef]

29. Bellamy, W.; Takase, M.; Yamauchi, K.; Wakabayashi, H.; Kawase, K.; Tomita, M. Identification of the bactericidal domain of lactoferrin. Biochim. Biophys. Acta 1992, 1121, 130-136. [CrossRef]

30. Kuwata, H.; Yip, T.T.; Tomita, M.; Hutchens, T.W. Direct evidence of the generation in human stomach of an antimicrobial peptide domain (lactoferricin) from ingested lactoferrin. BBA-Protein Struct. Mol. 1998, 1429, 129-141. [CrossRef]

31. Britigan, B.E.; Hayek, M.B.; Doebbeling, B.N.; Fick, R.B., Jr. Transferrin and lactoferrin undergo proteolytic cleavage in the pseudomonas aeruginosa-infected lungs of patients with cystic fibrosis. Infect. Immun. 1993, 61, 5049-5055.

32. Yamauchi, K.; Tomita, M.; Giehl, T.J.; Ellison, R.T., 3rd. Antibacterial activity of lactoferrin and a pepsin-derived lactoferrin peptide fragment. Infect. Immun. 1993, 61, 719-728. [PubMed]

33. Bellamy, W.; Takase, M.; Wakabayashi, H.; Kawase, K.; Tomita, M. Antibacterial spectrum of lactoferricin b, a potent bactericidal peptide derived from the n-terminal region of bovine lactoferrin. J. Appl. Bacteriol. 1992, 73, 472-479. [CrossRef] [PubMed]

34. Bruni, N.; Capucchio, M.T.; Biasibetti, E.; Pessione, E.; Cirrincione, S.; Giraudo, L.; Corona, A.; Dosio, F. Antimicrobial activity of lactoferrin-related peptides and applications in human and veterinary medicine. Molecules 2016, 21, 752. [CrossRef] [PubMed] 
35. Saffarzadeh, M.; Juenemann, C.; Queisser, M.A.; Lochnit, G.; Barreto, G.; Galuska, S.P.; Lohmeyer, J.; Preissner, K.T. Neutrophil extracellular traps directly induce epithelial and endothelial cell death: A predominant role of histones. PLoS ONE 2012, 7, e32366. [CrossRef] [PubMed]

36. Mishra, B.; von der Ohe, M.; Schulze, C.; Bian, S.; Makhina, T.; Loers, G.; Kleene, R.; Schachner, M. Functional role of the interaction between polysialic acid and extracellular histone h1. J. Neurosci. 2010, 30, 12400-12413. [CrossRef]

37. Shabir, U.; Ali, S.; Magray, A.R.; Ganai, B.A.; Firdous, P.; Hassan, T.; Nazir, R. Fish antimicrobial peptides (amp's) as essential and promising molecular therapeutic agents: A review. Microb. Pathog. 2018, 114, 50-56. [CrossRef]

38. Chaturvedi, P.; Bhat, R.A.H.; Pande, A. Antimicrobial peptides of fish: Innocuous alternatives to antibiotics. Rev. Aquac. 2018. [CrossRef]

39. Masso-Silva, J.A.; Diamond, G. Antimicrobial peptides from fish. Pharmaceuticals 2014, 7, 265-310. [CrossRef]

40. Parseghian, M.H.; Luhrs, K.A. Beyond the walls of the nucleus: The role of histones in cellular signaling and innate immunity. Biochem. Cell Biol. 2006, 84, 589-604. [CrossRef]

41. Park, I.Y.; Park, C.B.; Kim, M.S.; Kim, S.C. Parasin i, an antimicrobial peptide derived from histone h2a in the catfish, parasilurus asotus. FEBS Lett. 1998, 437, 258-262. [CrossRef]

42. Kawasaki, H.; Koyama, T.; Conlon, J.M.; Yamakura, F.; Iwamuro, S. Antimicrobial action of histone h2b in escherichia coli: Evidence for membrane translocation and DNA-binding of a histone $\mathrm{h} 2 \mathrm{~b}$ fragment after proteolytic cleavage by outer membrane proteinase t. Biochimie 2008, 90, 1693-1702. [CrossRef] [PubMed]

43. Silphaduang, U.; Hincke, M.T.; Nys, Y.; Mine, Y. Antimicrobial proteins in chicken reproductive system. Biochem. Biophys. Res. Commun. 2006, 340, 648-655. [CrossRef] [PubMed]

44. Li, G.H.; Mine, Y.; Hincke, M.T.; Nys, Y. Isolation and characterization of antimicrobial proteins and peptide from chicken liver. J. Pept. Sci. 2007, 13, 368-378. [CrossRef] [PubMed]

45. Hiemstra, P.S.; Eisenhauer, P.B.; Harwig, S.S.; van den Barselaar, M.T.; van Furth, R.; Lehrer, R.I. Antimicrobial proteins of murine macrophages. Infect. Immun. 1993, 61, 3038-3046.

46. Galuska, S.P.; Galuska, C.E.; Tharmalingam, T.; Zlatina, K.; Prem, G.; Husejnov, F.C.O.; Rudd, P.M.; Vann, W.F.; Reid, C.; Vionnet, J.; et al. In vitro generation of polysialylated cervical mucins by bacterial polysialyltransferases to counteract cytotoxicity of extracellular histones. FEBS J. 2017, 284, 1688-1699. [CrossRef]

47. Galuska, C.E.; Dambon, J.A.; Kuhnle, A.; Bornhofft, K.F.; Prem, G.; Zlatina, K.; Lutteke, T.; Galuska, S.P. Artificial polysialic acid chains as sialidase-resistant molecular-anchors to accumulate particles on neutrophil extracellular traps. Front. Immunol. 2017, 8, 1229. [CrossRef]

48. Zlatina, K.; Lütteke, T.; Galuska, S.P. Individual impact of distinct polysialic acid chain lengths on the cytotoxicity of histone h1, h2a, h2b, h3 and h4. Polymers 2017, 9, 720. [CrossRef]

49. Zlatina, K.; Galuska, S.P. Polysialic acid modulates only the antimicrobial properties of distinct histones. ACS Omega 2019, 4, 1601-1610. [CrossRef]

50. Hara, S.; Yamaguchi, M.; Takemori, Y.; Furuhata, K.; Ogura, H.; Nakamura, M. Determination of mono-o-acetylated n-acetylneuraminic acids in human and rat sera by fluorometric high-performance liquid chromatography. Anal. Biochem. 1989, 179, 162-166. [CrossRef]

51. Hara, S.; Takemori, Y.; Yamaguchi, M.; Nakamura, M.; Ohkura, Y. Fluorometric high-performance liquid chromatography of n-acetyl- and n-glycolylneuraminic acids and its application to their microdetermination in human and animal sera, glycoproteins, and glycolipids. Anal. Biochem. 1987, 164, 138-145. [CrossRef]

52. Inoue, S.; Lin, S.L.; Lee, Y.C.; Inoue, Y. An ultrasensitive chemical method for polysialic acid analysis. Glycobiology 2001, 11, 759-767. [CrossRef] [PubMed]

53. Kim, R.; Yokota, H.; Kim, S.H. Electrophoresis of proteins and protein-protein complexes in a native agarose gel. Anal. Biochem. 2000, 282, 147-149. [CrossRef] [PubMed]

54. Kumar, P.; Kizhakkedathu, J.N.; Straus, S.K. Antimicrobial peptides: Diversity, mechanism of action and strategies to improve the activity and biocompatibility in vivo. Biomolecules 2018, 8, 4. [CrossRef] [PubMed]

55. Hwang, P.M.; Zhou, N.; Shan, X.; Arrowsmith, C.H.; Vogel, H.J. Three-dimensional solution structure of lactoferricin b, an antimicrobial peptide derived from bovine lactoferrin. Biochemistry 1998, 37, 4288-4298. [CrossRef] 
56. Hallenbeck, P.C.; Vimr, E.R.; Yu, F.; Bassler, B.; Troy, F.A. Purification and properties of a bacteriophage-induced endo-n-acetylneuraminidase specific for poly-alpha-2,8-sialosyl carbohydrate units. J. Biol. Chem. 1987, 262, 3553-3561.

57. Rutishauser, U.; Watanabe, M.; Silver, J.; Troy, F.A.; Vimr, E.R. Specific alteration of ncam-mediated cell adhesion by an endoneuraminidase. J. Cell Biol. 1985, 101, 1842-1849. [CrossRef]

58. Curreli, S.; Arany, Z.; Gerardy-Schahn, R.; Mann, D.; Stamatos, N.M. Polysialylated neuropilin-2 is expressed on the surface of human dendritic cells and modulates dendritic cell-t lymphocyte interactions. J. Biol. Chem. 2007, 282, 30346-30356. [CrossRef]

59. Haiwen, Z.; Rui, H.; Bingxi, Z.; Qingfeng, G.; Jifeng, Z.; Xuemei, W.; Beibei, W. Oral administration of bovine lactoferrin-derived lactoferricin (lfcin) B could attenuate enterohemorrhagic Escherichia coli O157:H7 induced intestinal disease through improving intestinal barrier function and microbiota. J. Agric. Food Chem. 2019, 67, 3932-3945. [CrossRef]

(C) 2019 by the authors. Licensee MDPI, Basel, Switzerland. This article is an open access article distributed under the terms and conditions of the Creative Commons Attribution (CC BY) license (http://creativecommons.org/licenses/by/4.0/). 